\title{
The Effect of Obesity, Hypertension, Diabetes Mellitus, Alcohol, and Sleep Apnea on the Risk of Atrial Fibrillation
}

\author{
Zuzana Čarná ${ }^{1}$, Pavel Osmančík ${ }^{1}$ \\ ${ }^{1}$ Cardiocenter, Third Faculty of Medicine, Charles University Prague and University Hospital \\ Kralovske Vinohrady, Prague, Czech Republic
}

Received June 14, 2021

Accepted October 5, 2021

\begin{abstract}
Summary
Atrial fibrillation (AF) is the most common sustained cardiac arrhythmia associated with a two-fold increase in mortality caused by a higher risk of stroke and heart failure. Currently, AF is present in $\sim 2 \%$ of the general population, and its incidence and prevalence are increasing. Obesity, hypertension, diabetes mellitus, obstructive sleep apnea, and alcohol consumption increase the risk of AF. Each unit of increase in BMI increases the risk of $\mathrm{AF}$ by $3 \%$, and intensive weight loss is also associated with reduced AF recurrence. Hypertension increases the risk of AF by $50 \%$ in men and by $40 \%$ in women, and explains $\approx 20 \%$ of new AF cases. Patients with obstructive sleep apnea are at four times higher risk of developing AF than subjects without sleep apnea. Higher concentrations of pro-inflammatory cytokines, higher amounts of epicardial adipose tissue, and a higher degree of ventricular diffuse myocardial fibrosis are present in AF patients and patients with the aforementioned metabolic disorders. Several prospective cohort studies and randomized trials have been initiated to show whether weight loss and treatment of other risk factors will be associated with a reduction in $\mathrm{AF}$ recurrences.
\end{abstract}

\section{Key words}

Atrial fibrillation - Obesity - Hypertension - Risk factor modification

\section{Corresponding author}

Pavel Osmancik, Cardiocenter, Charles University Prague, Dept. Of Cardiology, Srobarova 50, 10034 Prague, Czech Republic. Email: pavel.osmancik@gmail.com

\section{Introduction}

Atrial fibrillation (AF) is the most common sustained and clinically relevant cardiac arrhythmia. It is associated with a two-fold increase in mortality caused by a higher risk of stroke and heart failure. It is also associated with increases in hospitalizations and emergency out-patient visits and worsens the quality of life. (Thrall et al. 2006, Wang et al. 2003) Currently, the estimated prevalence of $\mathrm{AF}$ is approximately $2 \%$ in North America and Europe, and several observational epidemiological studies predict that the prevalence and incidence will increase. (Heeringa et al. 2006, LloydJones et al. 2004, Piccini et al. 2012) Many expect the prevalence to increase by nearly 2.5 -fold over the next five decades. (Go et al. 2001) This trend can be partly explained by the aging of the population since the frequency of $\mathrm{AF}$ is known to increase with age.

A number of cardiac and non-cardiac conditions are associated with the risk of atrial fibrillation. Among structural cardiac diseases, valvular heart disease (especially mitral valve disease) and heart failure (HF) substantially increase the risk of AF. The main mechanism is structural and electrical atrial remodeling, although other factors play a role in HF patients. AF is also more often in patients with coronary artery disease without overt heart failure. Apart from cardiac disorders, there were recognized several genetic variants that can underlie AF (Fatkin et al. 2017). Furthermore, several metabolic conditions and ionic disbalances can also lead to AF development. The risk of AF is higher in patients with low potassium or magnesium levels (Farah et al. 2020), and AF is also more often in patients with advanced kidney disease or thyreopathy (Ding et al. 2021). In a large cohort of $>800,000$ patients, cancer was an independent factor for incident AF (Yun et al. 2021). 
Finally, the most significant risk factor for AF is age. In the long-term observation of more than 60 thousand patients, the AF incidence rate increases gradually from 0.9 per 1000 persons-years at age 40-49 years to 17.7 at ages $\geq 70$ years (Morseth et al. 2021).

A very important risk factor of AF is obesity and conditions often associated with obesity, such as hypertension, type 2 diabetes mellitus (T2DM), obstructive sleep apnea (OSA), and alcohol consumption. All these factors further contribute to the increased incidence of AF (Conen et al. 2009, Gami et al. 2007, Kodama et al. 2011, Wang et al. 2004). Recently, more attention has been paid to obesity: its incidence is increasing, and finally, AF related to obesity is potentially preventable. Previous studies have shown that lifestyle changes are effective in preventing diabetes and other complications associated with obesity. Therefore, in the present review, we focus on obesity and conditions often associated with obesity, their risk of $\mathrm{AF}$, possible pathophysiological mechanisms, and trends for future treatment interventions in obese patients with AF.

\section{Obesity and atrial fibrillation}

Long-term follow-up has shown that each unit of increase in body mass index (BMI) increases the risk of AF by $3 \%$ (95\% CI, 1\%-5\%) (Dublin et al. 2006, Tedrow et al. 2010). The effect of obesity on the increased risk of $\mathrm{AF}$ is undoubtedly multifactorial. Obesity is associated with left atrial dilatation, chronic pro-inflammatory status, and other conditions that increase the risk of AF, such as hypertension, T2DM, and obstructive sleep apnea. For instance, compared with adults with normal weight, adults with BMI $>40$ had a 7-fold higher risk for T2DM and a 6-fold higher risk for hypertension (Mokdad et al. 2003). Left atrial dilatation has been demonstrated in obese subjects by echocardiography and found to be independent of left ventricular size or the presence of left ventricular hypertrophy (Ayer et al. 2008). Obesity, especially central obesity, is associated with an increased volume of pericardial fat. There is also a very significant correlation between BMI and epicardial adipose tissue (EAT) thickness, as well as between EAT thickness, waist circumference, and visceral adipose tissue (Rabkin 2014). Obese patients have increased concentrations of circulating adhesion molecules such as Vascular Cell Adhesion Molecule-1 or intercellular adhesion molecule1, and their concentrations correlated with BMI.
Increased adhesion molecules production in visceral fat may provide a direct link between visceral adiposity and increased risk of cardiovascular complications (Bosanska et al. 2010).

\section{Epicardial adipose tissue and atrial fibrillation}

Several studies using cardiac imaging (especially computed tomography) have shown higher amounts of EAT in AF patients compared to healthy controls. According to a meta-analysis of studies focusing on EAT by Gaeta et al. the volume of epicardial fat was higher in AF patients by $48.0 \mathrm{ml}$ (95\% CI 25.2-70.8) compared to healthy controls (Gaeta et al. 2017). Furthermore, the amount of EAT was higher in non-paroxysmal AF patients by $29.6 \mathrm{ml}$ (95\% CI 12.7-46.5) compared to paroxysmal patients (Gaeta et al. 2017). Increased volume of pericardial fat volume has been shown to be highly associated with the development of paroxysmal and persistent AF, which was independent of other risk factors, including left atrial dilatation (Al Chekakie et al. 2010). The association between the amount of EAT and the future risk of AF has been described in several studies. For instance, of the 2,135 participants in the $3^{\text {rd }}$ generation cohort of the Framingham Heart Study, 162 participants developed AF during a median of 9.7 years. Based on an age- and sex-adjusted model, greater pericardial fat was associated with increased risk of incident $\mathrm{AF}$ with a hazard ratio of 1.17 (95\% CI 1.03-1.34) (Lee et al. 2016). Similarly, in a longitudinal study by Thanassoulis et al. (2010), higher volumes of pericardial fat were associated with higher risk of developing AF (odds ratio per standard deviation of pericardial fat volume $=1.28$ ). A recent meta-analysis suggested that the association of AF with EAT is stronger than the association with abdominal or general adiposity (Wong et al. 2016). Several studies have also identified EAT as a predictor of AF recurrence after catheter ablation (Al-Rawahi et al. 2015, Hatem et al. 2016). For instance, Mirolo et al. (2019) measured the EAT thickness in 206 patients undergoing cryoablation for AF. They found higher EAT thickness in patients with AF recurrence than without recurrence $(4.9 \pm 0.9 \mathrm{~mm}$ vs. $4.3 \pm$ $0.9 \mathrm{~mm}$ ), and the EAT thickness predicted the recurrence of AF also in the multivariate analysis (hazard ratio 1.96, $95 \% \mathrm{CI}$ 1.2-3.2). Many studies do not distinguish between pericardial fat and EAT. Pericardial fat is made up of the combination of EAT plus paracardial adipose 
tissue. Fat that is present on the external surface of the parietal pericardium is known as paracardial fat or mediastinal fat. EAT directly surrounds the heart, which is in direct contact with the coronary vasculature (Talman et al. 2014). EAT comes from the mesoderm and, in addition to adipocytes, also contains nerve tissue, inflammatory, stromal and immune cells, and paracardial adipose tissue, which comes from primitive thoracic mesenchyme and under physiological conditions covers $80 \%$ of the heart and makes up $20-50 \%$ of the heart mass (Corradi et al. 2004, Rosito et al. 2008). Fat stores directly in contact with the left atrium (i.e., EAT) are thought to contribute to the development of AF. EAT is biologically highly active. It produces several cytokines with proinflammatory effects as well as cytokines that play a significant role in the metabolism of the extracellular matrix (Fig. 1). Among the cytokines produced by EAT are cytokines with proliferative effects (vascular endothelial growth factor-1, thrombospondin-2, angiopoietin), growth and remodeling factors (activin A, transforming growth factor- $\beta 1$ (TGF- $\beta 1$ ), matrix metalloproteinases 1-13), adipocytokines (adiponectin, leptin, resistin, visfatin), and inflammatory cytokines. Among the particularly abundant cytokines in EAT, activin $\mathrm{A}$ and matrix metalloproteinases (MMPs) may mediate the fibrotic effect of EAT on the atrial myocardium (Hatem and Sanders 2014). MMPs are key regulators of extracellular matrix homeostasis, including collagen fibers and components of the basement membrane. Increased activity of several MMPs has been shown to contribute to interstitial atrial fibrosis in patients with AF. (Boixel et al. 2003) Increased amounts of EAT increase interstitial fibrosis in the atrial myocardium and contribute to the anisotropy of electrical impulse conduction in the atrial myocardium. Higher concentrations of proinflammatory cytokines (PICs) such as C-reactive protein (CRP), tumor necrosis factor- $\alpha$ (TNF- $\alpha$ ), interleukin-2, interleukin-6, interleukin-8, and monocyte chemoattractant protein-1 are also associated with a higher risk of AF in healthy individuals and also a higher risk of recurrence of AF after catheter ablation (Guo et al. 2012). These PICs have been previously found in higher concentrations in patients with pre-existing AF and those with sinus rhythm, as well as in healthy individuals with subsequently diagnosed AF. PICs are produced and secreted by EAT in large amounts, and their production is also increased in patients with other comorbidities associated with AF, such as the presence of ischemic cardiomyopathy, obesity, and diabetes (Hatem and Sanders 2014).

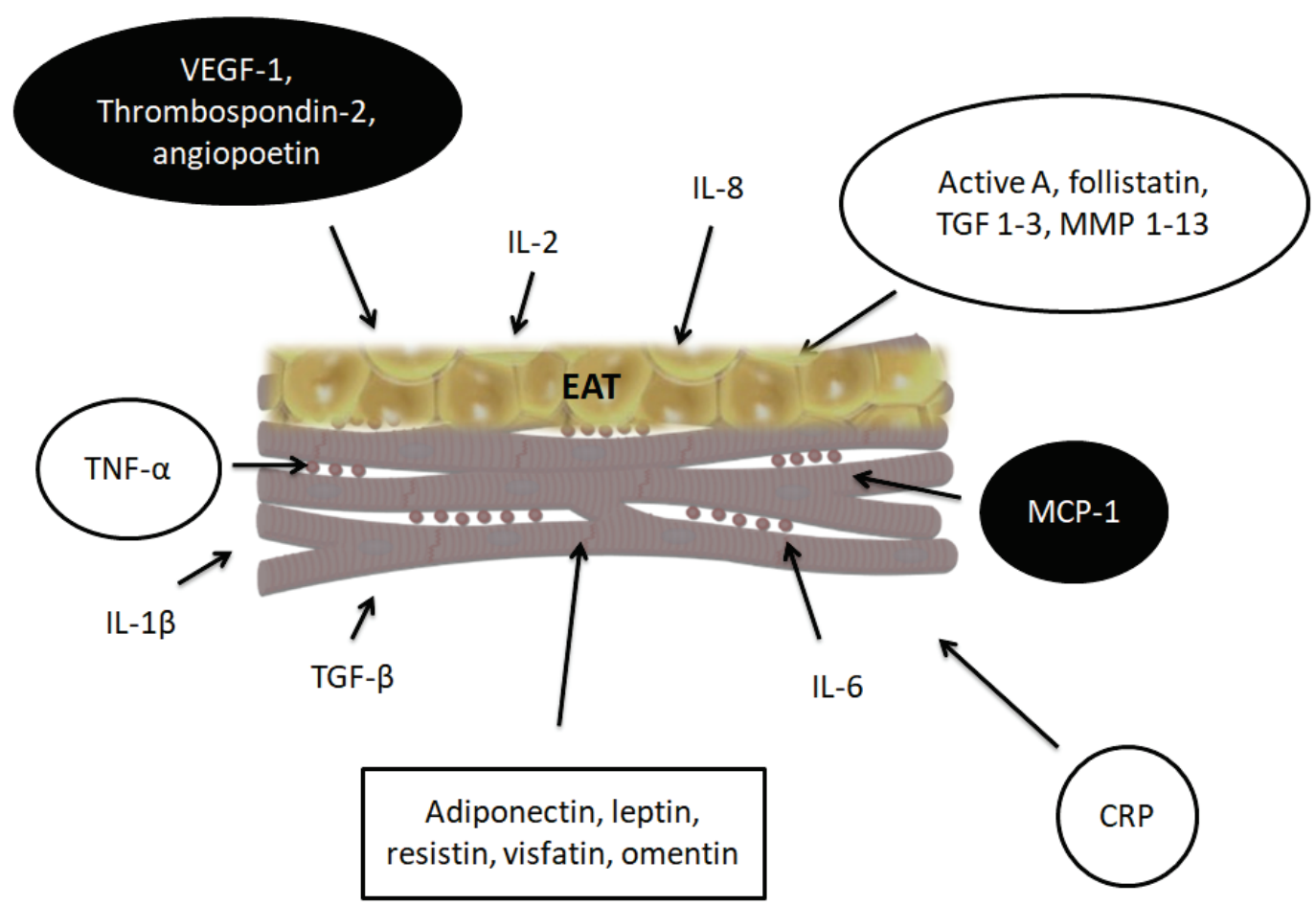

Fig. 1. Cytokines produced by epicardial adipose tissue involved in atrial remodeling. VEGF-1: vascular endothelial growth factor-1, IL-2: interleukin-2, IL-8: interleukin-8, TGF 1-3: transforming growth factor 1-3, MMP -1-13:metalloproteinase 1-13, TGF- $\beta$ : transforming growth factor- $\beta$, TNF-a: tumor necrosis factor- $a$, IL-1 $\beta$ : interleukin- $1 \beta$, IL-6: interleukin-6, CRP: C-reactive protein, MCP-1: monocyte chemoattractant protein-1 


\section{Hypertension as a risk factor of AF}

Hypertension is one of the most important factors that increase the risk of developing AF. Its presence increases the risk of AF by up to $50 \%$ in men and $40 \%$ in women (Benjamin et al. 1994). In the ARIC (Atherosclerosis Risk in Communities) study, hypertension was a major contributing factor to the subsequent development of $\mathrm{AF}$ and explained for $\approx 20 \%$ of new AF cases (Huxley et al. 2011), and in patients with known AF, hypertension is present in 60-80\% (Nabauer et al. 2009).

The pathophysiological consequences of hypertension result in decreased left ventricular compliance, diastolic dysfunction, and left ventricular hypertrophy. Hypertension also increases left ventricular stiffness, wall tension, filling pressure, provides a reserve of coronary pressure, activates the sympathetic nervous system and the renin-angiotensin-aldosterone (RAAS) system (Tadic et al. 2014). Cardiomyocyte expansion increases the expression of angiotensin-converting enzyme and consequently increases the production of angiotensin II and aldosterone, which further promotes cardiac hypertrophy, fibrosis, apoptosis, and myocyte vasoconstriction (Goette et al. 2000). Aldosterone also stimulates fibroblasts and promotes fibrosis by acting on mitogen-activated kinases (Stockand and Meszaros 2003). Another study suggests that angiotensin II additionally activates various inflammatory cytokines such as CRP, TNF- $\alpha$, and interleukin- 6 and stimulates the neutrophil response (Boos et al. 2006). Due to altered cytokine production, hypertension affects not only the cardiomyocytes of the ventricles but also the atria.

The direct relationship between blood pressure and AF observed in epidemiological studies indicated that non-pharmacological and pharmacological interventions that slow the progression from prehypertension to hypertension could slow the development of AF. Similarly, intensive blood pressure control in patients with hypertension may also reduce this risk. A metaanalysis of 18 randomized trials showed that intensive treatment of hypertension significantly reduced the risk of stroke by $20 \%$, myocardial infarction by $15 \%$, heart failure by $25 \%$, and cardiovascular death by $18 \%$ (Davis et al. 2002). In patients with HF or hypertension, treatment with angiotensin-converting enzyme (ACE) inhibitors, Angiotensin II receptor blockers (ARBs), or statins was very effective and associated with a decreased incidence of AF. Since all these drugs have positive effects on cardiac remodeling, an effort was made to use the potential of ACE inhibitors, ARBs, or statins in patients without standard indications for this treatment (e.g., without overt HF or hypertension) to determine if these agents could modify heart structure and decrease the incidence of AF beyond the benefit of treating the underlying heart disease. This strategy was called upstream AF therapy. However, several randomized controlled studies failed to demonstrate any effect of upstream therapies on AF burden or major cardiovascular outcomes (Savelieva et al. 2011).

\section{Alcohol and atrial fibrillation}

Chronic higher alcohol consumption is strongly associated with increased AF risk even in the absence of alcoholic cardiomyopathy. However, the relationship between light alcohol consumption and the risk of AF is less consistent. A prospective study by Luc Djoussé et al. (2004) demonstrated a dose-dependent association between longterm alcohol consumption and the risk of AF. The effect of alcohol was minimal and insignificant when alcohol consumption was $<36 \mathrm{~g}$ / day; however, consumption above this level was associated with an increased risk of AF by up to $34 \%$. Alcohol consumption was positively associated with incident $\mathrm{AF}$ in a recent, large, community-based pooled cohort of 107,845 individuals. The cut-off for statistically significantly increased risk for AF was observed with regular alcohol consumption of $2 \mathrm{~g} /$ day, and the HR for one drink (12 g) was 1.16 (1.11-1.22) (Csengeri et al. 2021). The HRs were similar for women and men, and an increasing non-linear relationship between alcohol consumption and incident $\mathrm{AF}$ was found. Finally, in the MORGAM consortium of observational studies with $>60$ thousand participants, high alcohol consumption significantly increased the risk of AF by $13 \%-18 \%$ at ages up to 70 years, but not in participants $\geq 70$ years (Morseth et al. 2021).

The intervention focused on a decrease in alcohol consumption had a positive effect on AF recurrence. The effect of alcohol abstinence was recently tested in a randomized controlled trial by Voskoboinik et al. (2020). From the 140 patients who underwent randomization, 70 were included in the abstinence group and 70 in the control group. Patients in the abstinence group reduced their alcohol intake by $87.5 \%$, while patients in the control group reduced their alcohol intake by $19.5 \%$. AF reoccurred in $53 \%$ of the abstinence group and $73 \%$ of the control group; the abstinence 
group also had a longer period before recurrence of $\mathrm{AF}$ than the control group (HR 0.55, $95 \%$ CI $0.36-0.84$ ).

\section{Obstructive sleep apnea and $\mathrm{AF}$}

Obstructive sleep apnea (OSA) is characterized by recurrent episodes of airway collapse resulting in occlusion of airflow during sleep. Approx. 3-7\% of the adult population is affected by OSA (Stradling and Davies 2004). Several observational studies have suggested that OSA patients are at increased risk of AF. Breathing-related sleep disorders are very prevalent, although under-diagnosed, conditions that affect between $21 \%-74 \%$ of the AF population, with the vast majority having OSA (Desteghe et al. 2021). The Sleep Heart Health Study found that the risk of AF among patients with OSA was 4-times higher (95\% CI 1.03-15.7) than those without OSA (Mehra et al. 2006).

Similarly, Gami et al. (2007) showed that for patients with OSA under 65 years, the hazard ratio of developing AF over the next five years was 3.3 (95\% CI 1.35-8.04). However, the quality of data in these observational studies was limited, and many of them were not adjusted for other risk factors associated with both OSA and AF. Thus, these studies suggest that OSA predisposes patients to AF, but, for now, it is not clear whether the relationship is independent of obesity, hypertension, diabetes, and other common risk factors. Hypoxemia and hypercapnia have direct adverse effects on the electrical stability of the heart (Adamantidis et al. 1986, McCord and Borzak 1998) and also activate chemoreceptors that can lead to vasoconstriction and increased blood pressure (Somers et al. 1989). In addition, a marked decrease in intrathoracic pressure associated with inspiration against airway obstruction can lead to sudden increases in the transmural pressure gradient (Naughton et al. 1995, Somers et al. 1993, Tkacova et al. 1998). High transmural pressure gradients associated with increased afterloads resulting from vasoconstriction induced by sleep apnea may increase the size of the left atrium (Bode et al. 2000, Jais et al. 2000). Among those with AF, OSA is significantly associated with reduced responses to rhythm control strategies and the risk of complications associated with AF, especially stroke (Dalgaard et al. 2020). Some (but not all) nonrandomized studies suggest that the treatment of OSA with continuous positive airway pressure can help to reduce $\mathrm{AF}$ recurrence and maintain SR (Latina et al. 2013). Unfortunately, there is no practical guidance on testing OSA in the AF population, and many AF patients with OSA remain undiagnosed and thus, untreated. In a survey among cardiologists treating AF patients, only $11 \%$ initiated systematic testing using a home sleep test or respiratory polygraphy (Desteghe et al. 2021).

\section{Type 2 Diabetes mellitus (T2DM) and AF}

Type 2 diabetes mellitus and elevated blood glucose have been associated with an increased risk of atrial fibrillation in several epidemiological studies. According to a meta-analysis of 32 cohort studies with more than 460 thousand diabetics (and $>10$ million nondiabetic controls), T2DM increases the risk of AF by $28 \%$ (RR 1.28, $95 \%$ CI 1.22-1.35). Furthermore, the risk of $\mathrm{AF}$ increased in prediabetes by $20 \%$, and there was a relatively linear dose-response relationship between increasing blood glucose and AF. An increase in blood glucose by $20 \mathrm{mg} / \mathrm{dl}(=1.1 \mathrm{mmol} / \mathrm{l})$ was associated with a relative risk of 1.11 (95\% CI 1.04-1.18) higher risk of AF (Aune et al. 2018). The risk of AF also increases with the duration of diabetes and poorer glycemic control (Dublin et al. 2010). There are several ways how diabetes can increase AF. T2DM is often associated with other conditions known to increase the risk of $\mathrm{AF}$, such as age, hypertension, and obesity. However, higher glucose levels can have a direct negative effect on atrial electrical remodeling. Diabetic patients have higher levels of CRP (Putz et al. 2004) and other markers of subclinical inflammation, which can lead to the progression of ventricular and atrial myocardial fibrosis. Diabetes is also associated with dilatation of the left atrium (Rutter et al. 2003), which could also be caused by an increase in atrial myocardial fibrosis. Diabetes also seems to have a direct effect on atrial electrophysiology parameters: in animal experiments with diabetic rabbits, diabetes and hyperglycemia prolong inter-atrial conduction time, increase the atrial effective refractory period and dispersion, and significantly increases the inducibility of AF (Liu et al. 2012). Importantly, diabetes is also associated with remodeling of the cardiac autonomic nervous system, including parasympathetic denervation and heterogeneous levels of sympathetic denervation (Otake et al. 2009). The disbalance in the autonomic nervous system is considered to be an important trigger of AF (Chen et al. 2006). Finally, patients with diabetes also have a higher risk of coronary artery disease and congestive heart failure, which further increases the risk of AF. 


\section{Myocardial atrial fibrosis relative to AF}

Cardiac fibrosis is an essential part of the structural remodeling that accompanies various cardiovascular diseases and present the common final pathway of almost all conditions that predispose to AF. In the pathophysiology of arrhythmias, fibrosis contributes significantly to the formation of re-entry substrate. Noninvasive assessment of arrhythmia substrate has progressed significantly in the last few years, and cardiac MRI scans now clearly characterize and describe scar tissue and cardiac fibrosis, which has significantly expanded the role of cardiac MRI (Simonetti et al. 2001).

Myofibroblasts are the most important cells involved in the pathophysiology of cardiac fibrosis. Myofibroblasts are formed by activating their precursor cells following myocardial injury, pressure overload, genetic abnormalities, viral infections, or toxic effects. The aforementioned causes activate myofibroblasts through mechanical conductors and signaling molecules, including TGF- $\beta 1$, endothelin-1, fibroblast growth factor, and cytokines (e.g., interleukin-1, interleukin-6, and TNF- $\alpha$ ) (Schroer and Merryman 2015). Myofibroblasts are derived from resident fibroblasts, bone marrowderived fibroblasts, epithelial-to-mesenchymal transition, and endothelial-to-mesenchymal transition (Kong et al. 2014). After activation, myofibroblasts increase the production of extracellular matrix proteins (Travers et al. 2016), $80 \%$ of which is collagen I. The resulting myocardial fibrosis (Barison et al. 2015) restricts oxygen supply and nutrition to cardiomyocytes and causes electrical and structural changes that predispose the heart to arrhythmias, heart failure, and ischemia. (Heymans et al. 2015). All discussed metabolic diseases increase myocardial fibrosis; however, the extent to which fibrotic changes observed in obese subjects reflect the presence and extent of metabolic dysregulation remains unclear. For instance, in patients with T2DM, an accumulation of type III collagen in the perimysium and perivascular areas has been documented (Fischer et al. 1984, Shimizu et al. 1993). Normotensive non-diabetic individuals with abdominal obesity were found to have concentric hypertrophy associated with diastolic dysfunction and evidence of increased collagen III turnover (Eschalier et al. 2014). The practical importance of measuring atrial fibrosis was demonstrated in the DECAAF study. In the study, Marrouche et al. (2014) measured atrial fibrosis in patients with AF (undergoing their first catheter ablation) using delayed enhancement MRI. Atrial fibrosis was categorized as stage 1 ( $<10 \%$ of the atrial wall), $2(\geq 10$ but $<20 \%$ ), 3 ( $\geq 20$ but $<30 \%$ ), and $4(\geq 30 \%)$. The amount of atrial tissue fibrosis was independently associated with the likelihood of recurrent arrhythmia; the unadjusted overall hazard ratio per $1 \%$ increase in left atrial fibrosis was 1.06 (95\% CI, 1.03-1.08). While the recurrence of $\mathrm{AF}$ was present in $15.3 \%$ of stage 1 patients by day 325 after ablation, it was $32.6 \%$ in stage $2,45.9 \%$ in stage 3 , and $69.4 \%$ in stage 4 patients. The results of this trial might be used to justify extending ablation strategies from pulmonary vein isolation (PVI) alone to a substrate-based approach. In the recently published ALICIA study, PVI plus MRI-guided fibrosis ablation had results similar to PVI only; however, the mean atrial fibrosis burden of patients enrolled in this study was only $12 \%$, and most patients had fibrosis inside the pulmonary vein area. (Bisbal et al. 2020) The concept of an MRI-guided fibrosis ablation is currently being studied in the DECAAF II trial (Marrouche et al. 2021). An improved understanding of the underlying mechanisms of atrial structural remodeling is crucial to improve the results of $\mathrm{AF}$ catheter ablations.

\section{Ventricular fibrosis and relation to $\mathbf{A F}$}

Myocardial fibrosis is the hallmark of cardiomyopathy of any origin and represents a potential link between heart failure and AF. Ventricular myocardial fibrosis includes replacement fibrosis (i.e., scar formation due to past ischemia) and interstitial fibrosis. Using a late gadolinium enhancement (LGE), MRI provides excellent visualization of replacement fibrosis. However, interstitial fibrosis is difficult to distinguish using LGE because it is diffusely and extensively distributed, causing the myocardial signal intensity may be almost isointense, making it hard to differentiate from normal tissue. Fortunately, recent innovations in MRI permit quantitative measurement of interstitial fibrosis using T1 mapping techniques.

In AF, ventricular fibrosis may be induced by arrhythmia or could reflect pre-existing cardiomyopathy. Importantly, it has been shown that SR maintenance can lead to a decrease in ventricular interstitial fibrosis. Ling et al. studied the amount of diffuse left ventricular (LV) myocardial fibrosis in patients with AF. Ninety subjects underwent cardiac examination using a $1.5 \mathrm{~T}$ MRI (40 patients with paroxysmal AF, 27 patients with persistent $\mathrm{AF}$, and 23 controls). Ventricular fibrosis assessed using T1 mapping was higher in AF patients than in controls, and persistent AF patients had a higher degree of ventricular fibrosis than paroxysmal patients 
(Ling et al. 2012). Zhao et al. (2019) studied the prognostic impact of ventricular fibrosis in patients with $\mathrm{AF}$ and heart failure. One hundred eight patients underwent MRI, including T1 mapping, and underwent catheter ablation for AF. The LV extracellular volume fraction was independently associated with worse outcomes, i.e., a higher risk of $\mathrm{CV}$ death or worsening $\mathrm{HF}$ with HR of 1.2 (95\% CI 1.1-1.4). In a study by Begg et al. (2020) increased ventricular fibrosis assessed usingT1 mapping was associated with increased left atrial pressure. In the CAMERA MRI study, patients with persistent $\mathrm{AF}$ and $\mathrm{HF}$ with reduced ejection fractions (EF) were randomized to catheter ablation or rate control therapy; all patients also underwent cardiac MRI at baseline and at six months (including myocardial T1 time). (Prabhu et al. 2018) At six months, patients in the catheter ablation group achieved SR significantly more often; and there was a significant reduction in myocardial T1 time compared with the rate control group. Improvement in myocardial $\mathrm{T} 1$ time with catheter ablation was also associated with significant improvements in the EF of the LV. These findings document the significant link between atrial fibrillation and fibrosis on the ventricular level. Several studies have shown that obesity is also associated with the progression of interstitial ventricular fibrosis. Due to the association with obesity with other comorbidities, such as hypertension or diabetes, which are also associated with a higher risk of developing interstitial fibrosis, it is difficult to identify the pure effect of obesity relative to the other mentioned factors. In a study by Kukuckseymen et al. (2020), patients with T2DM and obesity had increased myocardial native $\mathrm{T} 1$ times compared to patients with only one comorbidity (diabetes + obesity vs. diabetes, or obesity), which documents the negative synergic effect of metabolic disorders on ventricular fibrosis. Several studies have shown that obesity is associated with abnormal left ventricular diastolic function, dilation, and deterioration of left atrial function. (Pascual et al. 2003, Scaglione et al. 1992, Zarich et al. 1991) Therefore, diffuse myocardial fibrosis could represent a further link between metabolic disorders, especially obesity, and atrial fibrillation.

\section{Published interventional studies on weight reduction for sinus rhythm maintenance}

Several studies have highlighted the importance of treating the underlying cause of AF to achieve rhythm control and maintain sinus rhythm.

Abed et al. (2013) randomized 150 AF patients with $\mathrm{BMI}>27$ to weight management or control. The intervention group showed significantly greater weight reduction than the control group (14.3 and $3.6 \mathrm{~kg}$, resp., $\mathrm{p}<0.001)$. The primary endpoint, QoL determined using repeated QoL questionnaires starting 3-12 months after randomization, improved significantly in the weight management group compared to control patients. Similarly, the AF burden, measured using 24 Holter recording one year after randomization, decreased significantly in the weight management group (from $1176 \mathrm{~min}$ to $491 \mathrm{~min}$ ) and increased in the control group (from $1393 \mathrm{~min}$ to $1546 \mathrm{~min}$ ).

In the prospective non-randomized ARREST-AF study, 149 patients with BMIs over 27 were offered physician-led intensive management of risk factors (dietary change, regular exercise, etc.): 61 patients agreed with this intervention, and 88 formed a control group. Risk factor management aimed primarily at weight reduction led not only to a decrease in blood pressure, an improvement in the lipogram but also to a reduction in AF recurrences by $24 \%$ (Pathak et al. 2014). At the same time, there was a positive effect on structural remodeling, decreased left atrial volume, and decreased left ventricular hypertrophy.

The LEGACY study showed similar data. In this study, risk factor management was again offered and was primarily aimed at weight reduction. The study included 355 patients with a BMI over 27 who were referred for AF treatment. Based on weight loss, patients were divided into three groups, those with weight reductions above $10 \%, 3-9 \%$, and $<3 \%$. SR maintenance without AF recurrence was significantly different between groups (i.e. $45 \%, 22 \%$, and $13 \%$ of patients, respectively). (Pathak et al. 2015) Increasing physical activity is an equally important obesity intervention. In a study by Malmo 51 patients with paroxysmal AF were randomized to a 12-week interval aerobic training program or the control group, and time in AF was measured using an implantable ECG recorder. The AF burden remained unchanged in the control group, while the aerobic training group experienced a significant decrease in AF burden from $8.1 \%$ to $4.8 \%$ (Malmo et al. 2016).

On the other hand, surprising and less positive results were recently published in the SORT-AF trial (Supervised Obesity Reduction Trial for AF Ablation Patients). In this study, 133 patients with BMI 30-40 (34.9 on average) underwent catheter ablation for AF and 
were randomized to supervised weight reduction or usual care. The supervised intervention led to a significant reduction of weight and BMI, and no significant weight loss was present in the control group. AF burden measured 3-12 months after ablation was reduced significantly in both groups; in the intervention group from $21.6 \pm 36.0 \%$ to $3.7 \pm 12.5 \%$, and in controls from $22.4 \pm 36.8 \%$ to $4.21 \pm 11.3 \%$. However, no difference was observed in the decrease of the AF burden between both groups. (Gessler et al. 2021) Similarly, freedom of $\mathrm{AF}$ and time to first recurrent $\mathrm{AF}$ (both after three months of blanking period) were also not different between groups $(p=0.57)$. Only in the ancillary analyses of the subgroups was it shown that in patients with persistent $\mathrm{AF}$ ( $57 \%$ of the whole cohort), BMI reduction was associated with a significant decrease in AF recurrence compared to paroxysmal AF patients. Although patients' weight loss in the interventional arm was statistically significant compared to the baseline weight, it presented only $3.91 \%$ of the initial body weight. This weight loss might have been too little to show an effect on AF burden; in the LEGACY study, the most significant effect on $\mathrm{AF}$ freedom was in patients who lost $>10 \%$ of their initial body weight.

Table 1. A summary of the largest studies focused on metabolic interventions for AF treatment.

\begin{tabular}{|c|c|c|c|}
\hline \multicolumn{4}{|c|}{ ARREST-AF } \\
\hline \multicolumn{4}{|c|}{149 patients } \\
\hline Metabolic intervention: $61 \mathrm{pa}$ & ents & & Control group: 88 \\
\hline \multicolumn{4}{|c|}{$24 \%$ reduction of AF recurrences } \\
\hline \multicolumn{4}{|c|}{ LEGACY } \\
\hline \multicolumn{4}{|c|}{355 patients } \\
\hline Group 1 (10\% weight reduction) & Group 2 & ight reduction) & Group $3(<3 \%$ weight reduction) \\
\hline $45 \%$ patients without recurrence of $\mathrm{AF}$ & $22 \% \mathrm{w}$ & urrence of $\mathrm{AF}$ & $13 \%$ without recurrence of $\mathrm{AF}$ \\
\hline \multicolumn{4}{|c|}{ Aerobic Interval Training Reduces the Burden of Atrial Fibrillation in the Short Term } \\
\hline \multicolumn{4}{|c|}{55 patients } \\
\hline \multicolumn{4}{|c|}{26 patients 12 -week intervention period } \\
\hline \multicolumn{4}{|c|}{ Main time in $\mathrm{AF}$ increased from $10.4 \%$ to $14.6 \%$} \\
\hline
\end{tabular}

\section{Ongoing clinical studies on weight loss intervention in $\mathrm{AF}$ patients}

As shown, several studies have documented the effect of weight loss in obese AF patients, and several observational or randomized trials focusing on the effect of weight loss are ongoing. The HOBIT-AF study (Effect of Complex weight-reducing Interventions on Rhythm Control in Obese Subjects with Atrial Fibrillation, NCT 04560387) has a similar design as the SORT-AF but focuses on patients with even higher BMIs $(\geq 35)$ (Stolbova et al. 2021). Obese AF patients will be randomized after catheter ablation to the control group or the interventional group consisting of a physician-led program using various weight-reducing interventions, including bariatric surgery (sleeve gastrectomy). The primary outcome will be AF burden during the 18 months after randomization, as assessed using 14-d Holter recordings. Another similar study is the ISOLATE study
(Impact of Life-Style Modification on Ablation Outcome in Atrial Fibrillation, NCT02219841). This prospective randomized study evaluates the impact of aggressive lifestyle modification in terms of a calorie-controlled diet and supervised exercise on catheter ablation outcomes in overweight patients with atrial fibrillation. Participants in the intervention group will receive individual counseling sessions with an experienced dietitian and participate in a supervised exercise program; patients in the control group will be provided routine advice on a heart-healthy diet and lifestyle. The primary outcome is AF recurrence that will be assessed at 3, 6, and 12 months after the procedure using event recorders or Holter monitoring. The LOSE-AF (Can Weight Loss Help Patients With Atrial Fibrillation? NCT03713775) study is a prospective, randomized study comparing the effect of weight loss programs vs. standard care on AF reoccurrence after AF ablation in obese or overweight patients. Elderly individuals (60-85 years) with persistent 
$\mathrm{AF}$ and $\mathrm{BMI} \geq 27$ will be recruited. Participants will be randomly allocated (1:1) to either a meal replacement program with behavioral support (intervention) or standard care (control) for 32-36 weeks. Participants in the intervention arm will be referred to a local commercial counselor who will provide behavioral support, weight monitoring, and deliver formula meals. Participants randomized to the control group will receive the best standard care, consisting of a one-time, face-toface consultation regarding weight loss with a nurse at baseline. The primary endpoints are AF recurrence, defined as any ECG-confirmed episode of AF within eight months; AF burdens will be assessed using 14-day Holter monitoring.

\section{Conclusion}

With a current prevalence of $\approx 2 \%$ in the general population and a consistently growing incidence,
AF is rapidly achieving pandemic status. Since obesity and hypertension, the two most important risk factors for $\mathrm{AF}$, are extracardiac, the solution to the rising numbers of AF patients must comprehensively address multiple factors and focus on intracardiac and extracardiac causes. The progress of catheter-based techniques will need to be accompanied by an increase in our understanding of the metabolic conditions that lead to AF and the best ways to treat these conditions. Only integrated AF treatments, across all levels, can offer the best solutions for $\mathrm{AF}$ patients.

\section{Conflict of Interest}

There is no conflict of interest.

\section{Acknowledgements}

The study was supported by grant AZV MZ ČR NU2102-00388.

\section{References}

ABED HS, WITTERT GA, LEONG AP, SHIRAZI MG, BAHRAMI B, MIDDELDORP ME, LORIMER MF, LAU DH, ANTIC NA, BROOKS AG, ABHAYARATNA WP, KALMAN JM, SANDERS P: Effect of weight reduction and cardiometabolic risk factor management on symptom burden and severity in patients with atrial fibrillation. A randomized clinical trial. JAMA 310: 2050-60; 2013. https://doi.org/10.1001/jama.2013.280521

ADAMANTIDIS MM, CARON JF, DUPUIS BA: Triggered activity induced by combined mild hypoxia and acidosis in guinea-pig Purkinje fibers. J Mol Cell Cardiol 18: 1287-1299, 1986. https://doi.org/10.1016/S00222828(86)80432-1

AL CHEKAKIE MO, WELLES CC, METOYER R, IBRAHIM A, SHAPIRA AR, CYTRON J, SANTUCCI P, WILBER DJ, AKAR JG: Pericardial fat is independently associated with human atrial fibrillation. J Am Coll Cardiol 56: 784-788, 2010. https://doi.org/10.1016/j.jacc.2010.03.071

AL-RAWAHI M, PROIETTI R, THANASSOULIS G: Pericardial fat and atrial fibrillation: Epidemiology, mechanisms and interventions. Int J Cardiol 195: 98-103, 2015. https://doi.org/10.1016/j.ijcard.2015.05.129

AUNE D, FENG T, SCHLESINGER S, JANSZKY I, NORAT T, RIBOLI E: Diabetes mellitus, blood glucose and the risk of atrial fibrillation: A systematic review and meta-analysis of cohort studies. J Diabetes Complications 32: 501-511, 2018. https://doi.org/10.1016/j.jdiacomp.2018.02.004

AYER JG, ALMAFRAGY HS, PATEL AA, HELLYER RL, CELERMAJER DS: Body mass index is an independent determinant of left atrial size. Heart Lung Circ 17: 19-24, 2008. https://doi.org/10.1016/j.hlc.2007.04.006

BARISON A, GRIGORATOS C, TODIERE G, AQUARO GD: Myocardial interstitial remodelling in non-ischaemic dilated cardiomyopathy: insights from cardiovascular magnetic resonance. Heart Fail Rev 20: 731-749, 2015. https://doi.org/10.1007/s10741-015-9509-4

BEGG GA, SWOBODA PP, KARIM R, OESTERLEIN T, RHODE K, HOLDEN AV, GREENWOOD JP, SHANTSILA E, LIP GYH, PLEIN S, TAYEBJEE MH: Imaging, biomarker and invasive assessment of diffuse left ventricular myocardial fibrosis in atrial fibrillation. J Cardiovasc Magn Reson 22: 13, 2020. https://doi.org/10.1186/s12968-020-0603-y

BENJAMIN EJ, LEVY D, VAZIRI SM, D'AGOSTINO RB, BELANGER AJ, WOLF PA: Independent risk factors for atrial fibrillation in a population-based cohort. The Framingham Heart Study. JAMA 271: 840-844, 1994. https://doi.org/10.1001/jama.271.11.840 
BISBAL F, BENITO E, TEIS A, ALARCON F, SARRIAS A, CAIXAL G, VILLUENDAS R, GARRE P, SOTO N, COZZARI J, GUASCH E, JUNCA G, PRAT-GONZALEZ S, PEREA RJ, BAZAN V, TOLOSANA JM, ARBELO E, BAYES-GENIS A, MONT L: Magnetic Resonance Imaging-Guided Fibrosis Ablation for the Treatment of Atrial Fibrillation: The ALICIA Trial. Circ Arrhythm Electrophysiol 13: e008707, 2020. https://doi.org/10.1161/CIRCEP.120.008707

BODE F, KATCHMAN A, WOOSLEY RL, FRANZ MR: Gadolinium decreases stretch-induced vulnerability to atrial fibrillation. Circulation 101: 2200-2205, 2000. https://doi.org/10.1161/01.CIR.101.18.2200

BOIXEL C, FONTAINE V, RUCKER-MARTIN C, MILLIEZ P, LOUEDEC L, MICHEL JB, JACOB MP, HATEM $\mathrm{SN}$ : Fibrosis of the left atria during progression of heart failure is associated with increased matrix metalloproteinases in the rat. J Am Coll Cardiol 42: 336-344, 2003. https://doi.org/10.1016/S07351097(03)00578-3

BOOS CJ, ANDERSON RA, LIP GY: Is atrial fibrillation an inflammatory disorder? Eur Heart J 27: 136-149, 2006. https://doi.org/10.1093/eurhearti/ehi645

BOSANSKA L, MICHALSKY D, LACINOVA Z, DOSTALOVA I, BARTLOVA M, HALUZIKOVA D, MATOULEK M, KASALICKY M, HALUZIK M: The influence of obesity and different fat depots on adipose tissue gene expression and protein levels of cell adhesion molecules. Physiol Res 59: 79-88, 2010. https://doi.org/10.33549/physiolres.931705

CHEN J, WASMUND SL, HAMDAN MH: Back to the future: the role of the autonomic nervous system in atrial fibrillation. Pacing Clin Electrophysiol 29: 413-421, 2006. https://doi.org/10.1016/j.futures.2005.09.002

CONEN D, TEDROW UB, KOPLAN BA, GLYNN RJ, BURING JE, ALBERT CM: Influence of systolic and diastolic blood pressure on the risk of incident atrial fibrillation in women. Circulation 119: 2146-2152, 2009. https://doi.org/10.1161/CIRCULATIONAHA.108.830042

CORRADI D, MAESTRI R, CALLEGARI S, PASTORI P, GOLDONI M, LUONG TV, BORDI C: The ventricular epicardial fat is related to the myocardial mass in normal, ischemic and hypertrophic hearts. Cardiovasc Pathol 13: 313-316, 2004. https://doi.org/10.1016/j.carpath.2004.08.005

CSENGERI D, SPRUNKER NA, DI CASTELNUOVO A, NIIRANEN T, VISHRAM-NIELSEN JK, COSTANZO S, SODERBERG S, JENSEN SM, VARTIAINEN E, DONATI MB, MAGNUSSEN C, CAMEN S, GIANFAGNA F, LOCHEN ML, KEE F, KONTTO J, MATHIESEN EB, KOENIG W, STEFAN B, DE GAETANO G, JORGENSEN T, KUULASMAA K, ZELLER T, SALOMAA V, IACOVIELLO L, SCHNABEL RB: Alcohol consumption, cardiac biomarkers, risk of atrial fibrillation and adverse outcomes. Eur Heart J 42: 1170-1177, 2021. https://doi.org/10.1093/eurheartj/ehaa953

DALGAARD F, NORTH R, PIEPER K, FONAROW GC, KOWEY PR, GERSH BJ, MAHAFFEY KW, POKORNEY S, STEINBERG BA, NACCARRELLI G, ALLEN LA, REIFFEL JA, EZEKOWITZ M, SINGER DE, CHAN PS, PETERSON ED, PICCINI JP: Risk of major cardiovascular and neurologic events with obstructive sleep apnea among patients with atrial fibrillation. Am Heart J 223: 65-71, 2020. https://doi.org/10.1016/j.ahj.2020.01.001

DAVIS BR, CUTLER JA, FURBERG CD, WRIGHT JT, FARBER MA, FELICETTA JV, STOKES JD, GROUP ACR: Relationship of antihypertensive treatment regimens and change in blood pressure to risk for heart failure in hypertensive patients randomly assigned to doxazosin or chlorthalidone: further analyses from the Antihypertensive and Lipid-Lowering treatment to prevent Heart Attack Trial. Ann Intern Med 137: 313-320, 2002. https://doi.org/10.7326/0003-4819-137-5 Part_1-200209030-00006

DESTEGHE L, HENDRIKS JML, HEIDBUCHEL H, POTPARA TS, LEE GA, LINZ D: Obstructive sleep apnoea testing and management in atrial fibrillation patients: a joint survey by the European Heart Rhythm Association (EHRA) and the Association of Cardiovascular Nurses and Allied Professions (ACNAP). Europace 2021. https://doi.org/10.1093/europace/euab109

DING WY, GUPTA D, WONG CF, LIP GYH: Pathophysiology of atrial fibrillation and chronic kidney disease. Cardiovasc Res 117: 1046-1059, 2021. https://doi.org/10.1093/cvr/cvaa258

DJOUSSE L, LEVY D, BENJAMIN EJ, BLEASE SJ, RUSS A, LARSON MG, MASSARO JM, D'AGOSTINO RB, WOLF PA, ELLISON RC: Long-term alcohol consumption and the risk of atrial fibrillation in the Framingham Study. Am J Cardiol 93: 710-713, 2004. https://doi.org/10.1016/j.amjcard.2003.12.004 
DUBLIN S, FRENCH B, GLAZER NL, WIGGINS KL, LUMLEY T, PSATY BM, SMITH NL, HECKBERT SR: Risk of new-onset atrial fibrillation in relation to body mass index. Arch Intern Med 166: 2322-2328, 2006. https://doi.org/10.1001/archinte.166.21.2322

DUBLIN S, GLAZER NL, SMITH NL, PSATY BM, LUMLEY T, WIGGINS KL, PAGE RL, HECKBERT SR: Diabetes mellitus, glycemic control, risk of atrial fibrillation. J Gen Intern Med 25: 853-858, 2010. https://doi.org/10.1007/s11606-010-1340-y

ESCHALIER R, ROSSIGNOL P, KEARNEY-SCHWARTZ A, ADAMOPOULOS C, KARATZIDOU K, FAY R, MANDRY D, MARIE PY, ZANNAD F: Features of cardiac remodeling, associated with blood pressure and fibrosis biomarkers, are frequent in subjects with abdominal obesity. Hypertension 63: 740-746, 2014. https://doi.org/10.1161/HYPERTENSIONAHA.113.02419

FARAH R, NASSAR M, ABORAYA B, NSEIR W: Low serum potassium levels are associated with the risk of atrial fibrillation. Acta Cardiol 1-4, 2020. https://doi.org/10.1080/00015385.2020.1799573

FATKIN D, SANTIAGO CF, HUTTNER IG, LUBITZ SA, ELLINOR PT: Genetics of atrial fibrillation: state of the art in 2017. Heart Lung Circ 26: 894-901, 2017. https://doi.org/10.1016/j.hlc.2017.04.008

FISCHER VW, BARNER HB, LAROSE LS: Pathomorphologic aspects of muscular tissue in diabetes mellitus. Hum Pathol 15: 1127-1136, 1984. https://doi.org/10.1016/S0046-8177(84)80307-X

GAETA M, BANDERA F, TASSINARI F, CAPASSO L, CARGNELUTTI M, PELISSERO G, MALAVAZOS AE, RICCI C: Is epicardial fat depot associated with atrial fibrillation? A systematic review and meta-analysis. Europace 19: 747-752, 2017. https://doi.org/10.1093/europace/euw398

GAMI AS, HODGE DO, HERGES RM, OLSON EJ, NYKODYM J, KARA T, SOMERS VK: Obstructive sleep apnea, obesity, the risk of incident atrial fibrillation. J Am Coll Cardiol 49: 565-571, 2007. https://doi.org/10.1016/j.jacc.2006.08.060

GESSLER N, WILLEMS S, STEVEN D, ABERLE J, AKBULAK RO, GOSAU N, HOFFMANN BA, MEYER C, SULTAN A, TILZ R, VOGLER J, WOHLMUTH P, SCHOLZ S, GUNAWARDENE MA, EICKHOLT C, LUKER J: Supervised obesity reduction trial for af ablation patients: results from the SORT-AF trial. Europace 2021. https://doi.org/10.1093/europace/euab122

Go AS, Hylek EM, Phillips KA, Chang Y, Henault LE, Selby JV, Singer DE. Prevalence of diagnosed atrial fibrillation in adults: national implications for rhythm management and stroke prevention: the AnTicoagulation and Risk Factors in Atrial Fibrillation (ATRIA) Study. JAMA 285: 2370-2375, 2001. https://doi.org/10.1001/jama.285.18.2370

GOETTE A, STAACK T, ROCKEN C, ARNDT M, GELLER JC, HUTH C, ANSORGE S, KLEIN HU, LENDECKEL U: Increased expression of extracellular signal-regulated kinase and angiotensin-converting enzyme in human atria during atrial fibrillation. J Am Coll Cardiol 35: 1669-1677, 2000. https://doi.org/10.1016/S0735-1097(00)00611-2

GUO Y, LIP GY, APOSTOLAKIS S: Inflammation in atrial fibrillation. J Am Coll Cardiol 60: 2263-2270, 2012. https://doi.org/10.1016/j.jacc.2012.04.063

HATEM SN, SANDERS P: Epicardial adipose tissue and atrial fibrillation. Cardiovasc Res 102: $205-213,2014$. https://doi.org/10.1093/cvr/cvu045

HATEM SN, REDHEUIL A, GANDJBAKHCH E: Cardiac adipose tissue and atrial fibrillation: the perils of adiposity. Cardiovasc Res 109: 502-509, 2016. https://doi.org/10.1093/cvr/cvw001

HEERINGA J, VAN DER KUIP DA, HOFMAN A, KORS JA, VAN HERPEN G, STRICKER BH, STIJNEN T, LIP GY, WITTEMAN JC: Prevalence, incidence and lifetime risk of atrial fibrillation: the Rotterdam study. Eur Heart J 27: 949-953, 2006. https://doi.org/10.1093/eurheartj/ehi825

HEYMANS S, GONZALEZ A, PIZARD A, PAPAGEORGIOU AP, LOPEZ-ANDRES N, JAISSER F, THUM T, ZANNAD F, DIEZ J: Searching for new mechanisms of myocardial fibrosis with diagnostic and/or therapeutic potential. Eur J Heart Fail 17: 764-771, 2015. https://doi.org/10.1002/ejhf.312

HUXLEY RR, LOPEZ FL, FOLSOM AR, AGARWAL SK, LOEHR LR, SOLIMAN EZ, MACLEHOSE R, KONETY $\mathrm{S}$, ALONSO A: Absolute and attributable risks of atrial fibrillation in relation to optimal and borderline risk factors: the Atherosclerosis Risk in Communities (ARIC) study. Circulation 123: 1501-1508, 2011. https://doi.org/10.1161/CIRCULATIONAHA.110.009035 
JAIS P, PENG JT, SHAH DC, GARRIGUE S, HOCINI M, YAMANE T, HAISSAGUERRE M, BAROLD SS, ROUDAUT R, CLEMENTY J: Left ventricular diastolic dysfunction in patients with so-called lone atrial fibrillation. $\mathrm{J}$ Cardiovasc Electrophysiol 11: 623-625, 2000. https://doi.org/10.1111/j.15408167.2000.tb00023.X

KODAMA S, SAITO K, TANAKA S, HORIKAWA C, SAITO A, HEIANZA Y, ANASAKO Y, NISHIGAKI Y, YACHI Y, IIDA KT, OHASHI Y, YAMADA N, SONE H: Alcohol consumption and risk of atrial fibrillation: a meta-analysis. J Am Coll Cardiol 57: 427-436, 2011. https://doi.org/10.1016/j.jacc.2010.08.641

KONG P, CHRISTIA P, FRANGOGIANNIS NG: The pathogenesis of cardiac fibrosis. Cell Mol Life Sci 71: 549-574, 2014. https://doi.org/10.1007/s00018-013-1349-6

KUCUKSEYMEN S, NEISIUS U, RODRIGUEZ J, TSAO CW, NEZAFAT R: Negative synergism of diabetes mellitus and obesity in patients with heart failure with preserved ejection fraction: a cardiovascular magnetic resonance study. Int J Cardiovasc Imaging 36: 2027-2038, 2020. https://doi.org/10.1007/s10554-020-01915-4

LATINA JM, ESTES NA, 3RD, GARLITSKI AC: The Relationship between Obstructive Sleep Apnea and Atrial Fibrillation: A Complex Interplay. Pulm Med 2013: 621736, 2013. https://doi.org/10.1155/2013/621736

LEE JJ, YIN X, HOFFMANN U, FOX CS, BENJAMIN EJ: Relation of pericardial fat, intrathoracic fat, abdominal visceral fat with incident atrial fibrillation (from the Framingham Heart Study). Am J Cardiol 118: 1486-1492, 2016. https://doi.org/10.1016/j.amjcard.2016.08.011

LING LH, KISTLER PM, ELLIMS AH, ILES LM, LEE G, HUGHES GL, KALMAN JM, KAYE DM, TAYLOR AJ: Diffuse ventricular fibrosis in atrial fibrillation: noninvasive evaluation and relationships with aging and systolic dysfunction. J Am Coll Cardiol 60: 2402-2408, 2012. https://doi.org/10.1016/j.jacc.2012.07.065

LIU C, FU H, LI J, YANG W, CHENG L, LIU T, LI G: Hyperglycemia aggravates atrial interstitial fibrosis, ionic remodeling and vulnerability to atrial fibrillation in diabetic rabbits. Anadolu Kardiyol Derg 12: 543-550, 2012. https://doi.org/10.5152/akd.2012.188

LLOYD-JONES DM, WANG TJ, LEIP EP, LARSON MG, LEVY D, VASAN RS, D'AGOSTINO RB, MASSARO JM, BEISER A, WOLF PA, BENJAMIN EJ: Lifetime risk for development of atrial fibrillation: the $\begin{array}{lllll}\text { Framingham Heart } \quad \text { Study. } & \text { Circulation }\end{array}$ https://doi.org/10.1161/01.CIR.0000140263.20897.42

MALMO V, NES BM, AMUNDSEN BH, TJONNA AE, STOYLEN A, ROSSVOLL O, WiSlOFF U, LOENNECHEN JP: Aerobic interval training reduces the burden of atrial fibrillation in the short term: a randomized trial. Circulation 133: 466-473, 2016. https://doi.org/10.1161/CIRCULATIONAHA.115.018220

MARROUCHE NF, GREENE T, DEAN JM, KHOLMOVSKI EG, BOER LM, MANSOUR M, CALKINS H, MARCHLINSKI F, WILBER D, HINDRICKS G, MAHNKOPF C, JAIS P, SANDERS P, BRACHMANN J, BAX J, DAGHER L, WAZNI O, AKOUM N, INVESTIGATORS DI: Efficacy of LGE-MRI-guided fibrosis ablation versus conventional catheter ablation of atrial fibrillation: The DECAAF II trial: Study design. J Cardiovasc Electrophysiol 32: 916-924, 2021. https://doi.org/10.1111/jce.14957

MARROUCHE NF, WILBER D, HINDRICKS G, JAIS P, AKOUM N, MARCHLINSKI F, KHOLMOVSKI E, BURGON N, HU N, MONT L, DENEKE T, DUYTSCHAEVER M, NEUMANN T, MANSOUR M, MAHNKOPF C, HERWEG B, DAOUD E, WISSNER E, BANSMANN P, BRACHMANN J: Association of atrial tissue fibrosis identified by delayed enhancement MRI and atrial fibrillation catheter ablation: the DECAAF study. JAMA 311: 498-506, 2014. https://doi.org/10.1001/jama.2014.3

MCCORD J, BORZAK S: Multifocal atrial tachycardia. Chest 113: 203-209, 1998. https://doi.org/10.1378/chest.113.1.203

MEHRA R, BENJAMIN EJ, SHAHAR E, GOTTLIEB DJ, NAWABIT R, KIRCHNER HL, SAHADEVAN J, REDLINE S, SLEEP HEART HEALTH S: Association of nocturnal arrhythmias with sleep-disordered breathing: The Sleep Heart Health Study. Am J Respir Crit Care Med 173: 910-916, 2006. https://doi.org/10.1164/rccm.200509-1442OC

MIROLO A, VIART G, SAVOURE A, GODIN B, RAITIERE O, ELTCHANINOFF H, ANSELME F: Epicardial fat thickness predicts atrial fibrillation recurrence after a first pulmonary vein isolation procedure using a secondgeneration cryoballoon. Arch Cardiovasc Dis 112: 314-322, 2019. https://doi.org/10.1016/j.acvd.2018.11.011 
MOKDAD AH, FORD ES, BOWMAN BA, DIETZ WH, VINICOR F, BALES VS, MARKS JS: Prevalence of obesity, diabetes, obesity-related health risk factors, 2001. JAMA 289: 76-79, 2003. https://doi.org/10.1001/jama.289.1.76

MORSETH B, GEELHOED B, LINNEBERG A, JOHANSSON L, KUULASMAA K, SALOMAA V, IACOVIELLO L, COSTANZO S, SODERBERG S, NIIRANEN TJ, VISHRAM-NIELSEN JKK, NJOLSTAD I, WILSGAARD T, MATHIESEN EB, LOCHEN ML, ZELLER T, BLANKENBERG S, OJEDA FM, SCHNABEL RB, CONSORTIUM M: Age-specific atrial fibrillation incidence, attributable risk factors and risk of stroke and mortality: results from the MORGAM Consortium. Open Heart 8: 2021. https://doi.org/10.1136/openhrt-2021-001624

NABAUER M, GERTH A, LIMBOURG T, SCHNEIDER S, OEFF M, KIRCHHOF P, GOETTE A, LEWALTER T, RAVENS U, MEINERTZ T, BREITHARDT G, STEINBECK G: The Registry of the German Competence NETwork on Atrial Fibrillation: patient characteristics and initial management. Europace 11: 423-434, 2009. https://doi.org/10.1093/europace/eun369

NAUGHTON MT, RAHMAN MA, HARA K, FLORAS JS, BRADLEY TD: Effect of continuous positive airway pressure on intrathoracic and left ventricular transmural pressures in patients with congestive heart failure. Circulation 91: 1725-1731, 1995. https://doi.org/10.1161/01.CIR.91.6.1725

OTAKE H, SUZUKI H, HONDA T, MARUYAMA Y: Influences of autonomic nervous system on atrial arrhythmogenic substrates and the incidence of atrial fibrillation in diabetic heart. Int Heart J 50: 627-641, 2009. https://doi.org/10.1536/ihj.50.627

PASCUAL M, PASCUAL DA, SORIA F, VICENTE T, HERNANDEZ AM, TEBAR FJ, VALDES M: Effects of isolated obesity on systolic and diastolic left ventricular function. Heart 89: 1152-1156, 2003. https://doi.org/10.1136/heart.89.10.1152

PATHAK RK, MIDDELDORP ME, LAU DH, MEHTA AB, MAHAJAN R, TWOMEY D, ALASADY M, HANLEY L, ANTIC NA, MCEVOY RD, KALMAN JM, ABHAYARATNA WP, SANDERS P: Aggressive risk factor reduction study for atrial fibrillation and implications for the outcome of ablation: the ARREST-AF cohort study. J Am Coll Cardiol 64: 2222-2231, 2014. https://doi.org/10.1016/j.jacc.2014.09.028

PATHAK RK, MIDDELDORP ME, MEREDITH M, MEHTA AB, MAHAJAN R, WONG CX, TWOMEY D, ELLIOTT AD, KALMAN JM, ABHAYARATNA WP, LAU DH, SANDERS P: Long-term effect of goal-directed weight management in an atrial fibrillation cohort: a long-term follow-up study (Legacy). J Am Coll Cardiol 65: 2159-2169, 2015. https://doi.org/10.1016/j.jacc.2015.03.002

PICCINI JP, HAMMILL BG, SINNER MF, JENSEN PN, HERNANDEZ AF, HECKBERT SR, BENJAMIN EJ, CURTIS LH: Incidence and prevalence of atrial fibrillation and associated mortality among Medicare beneficiaries, 1993-2007. Circ Cardiovasc Qual Outcomes 5: 85-93, 2012. https://doi.org/10.1161/CIRCOUTCOMES.111.962688

PRABHU S, COSTELLO BT, TAYLOR AJ, GUTMAN SJ, VOSKOBOINIK A, MCLELLAN AJA, PECK KY, SUGUMAR H, ILES L, PATHIK B, NALLIAH CJ, WONG GR, AZZOPARDI SM, LEE G, MARIANI J, KAYE DM, LING LH, KALMAN JM, KISTLER PM: Regression of diffuse ventricular fibrosis following restoration of sinus rhythm with catheter ablation in patients with atrial fibrillation and systolic dysfunction: a substudy of the CAMERA MRI Trial. JACC Clin Electrophysiol 4: 999-1007, 2018. https://doi.org/10.1016/j.jacep.2018.04.013

PUTZ DM, GOLDNER WS, BAR RS, HAYNES WG, SIVITZ WI: Adiponectin and C-reactive protein in obesity, type 2 diabetes, monodrug therapy. Metabolism 53: 2004. https://doi.org/10.1016/j.metabol.2004.06.013

RABKIN SW: The relationship between epicardial fat and indices of obesity and the metabolic syndrome: a systematic review and meta-analysis. Metab Syndr Relat Disord 12: 31-42, 2014. https://doi.org/10.1089/met.2013.0107

ROSITO GA, MASSARO JM, HOFFMANN U, RUBERG FL, MAHABADI AA, VASAN RS, O'DONNELL CJ, FOX CS: Pericardial fat, visceral abdominal fat, cardiovascular disease risk factors, vascular calcification in a community-based sample: the Framingham Heart Study. Circulation 117: 605-613, 2008. https://doi.org/10.1161/CIRCULATIONAHA.107.743062 
RUTTER MK, PARISE H, BENJAMIN EJ, LEVY D, LARSON MG, MEIGS JB, NESTO RW, WILSON PW, VASAN RS: Impact of glucose intolerance and insulin resistance on cardiac structure and function: sex-related differences in the Framingham Heart Study. Circulation 107: 448-454, 2003. https://doi.org/10.1161/01.CIR.0000045671.62860.98

SAVELIEVA I, KAKOUROS N, KOURLIOUROS A, CAMM AJ: Upstream therapies for management of atrial fibrillation: review of clinical evidence and implications for European Society of Cardiology guidelines. Part I: primary prevention. Europace 13: 308-328, 2011. https://doi.org/10.1093/europace/eur002

SCAGLIONE R, DICHIARA MA, INDOVINA A, LIPARI R, GANGUZZA A, PARRINELLO G, CAPUANA G, MERLINO G, LICATA G: Left ventricular diastolic and systolic function in normotensive obese subjects: influence of degree and duration of obesity. Eur Heart J 13: 738-742, 1992. https://doi.org/10.1093/oxfordjournals.eurheartj.a060249

SCHROER AK, MERRYMAN WD: Mechanobiology of myofibroblast adhesion in fibrotic cardiac disease. J Cell Sci 128: 1865-1875, 2015. https://doi.org/10.1242/jcs.162891

SHIMIZU M, UMEDA K, SUGIHARA N, YOSHIO H, INO H, TAKEDA R, OKADA Y, NAKANISHI I: Collagen remodelling in myocardia of patients with diabetes. J Clin Pathol 46: 32-36, 1993. https://doi.org/10.1136/jcp.46.1.32

SIMONETTI OP, KIM RJ, FIENO DS, HILLENBRAND HB, WU E, BUNDY JM, FINN JP, JUDD RM: An improved MR imaging technique for the visualization of myocardial infarction. Radiology 218: 215-223, 2001. https://doi.org/10.1148/radiology.218.1.r01ja50215

SOMERS VK, DYKEN ME, SKINNER JL: Autonomic and hemodynamic responses and interactions during the Mueller maneuver in humans. J Auton Nerv Syst 44: 253-259, 1993. https://doi.org/10.1016/0165$\underline{1838(93) 90038-\mathrm{V}}$

SOMERS VK, MARK AL, ZAVALA DC, ABBOUD FM: Influence of ventilation and hypocapnia on sympathetic nerve responses to hypoxia in normal humans. J Appl Physiol (1985) 67: 2095-2100, 1989. https://doi.org/10.1152/jappl.1989.67.5.2095

STOCKAND JD, MESZAROS JG: Aldosterone stimulates proliferation of cardiac fibroblasts by activating Ki-RasA and MAPK1/2 signaling. Am J Physiol Heart Circ Physiol 284: H176-184, 2003. https://doi.org/10.1152/ajpheart.00421.2002

STOLBOVA K, NOVODVORSKY P, JAKUBIKOVA I, DVORAKOVA I, MRAZ M, WICHTERLE D, KAUTZNER J, HALUZIK M: Effect of Complex weight-reducing interventions on rhythm control in obese individuals with atrial fibrillation following catheter ablation: a study protocol. Adv Ther 38: 2007-2016, 2021. https://doi.org/10.1007/s12325-021-01667-0

STRADLING JR, DAVIES RJ: Sleep. 1: Obstructive sleep apnoea/hypopnoea syndrome: definitions, epidemiology, natural history. Thorax 59: 73-78, 2004. https://doi.org/10.1136/thx.2003.007161

TADIC M, IVANOVIC B, CUSPIDI C: What do we actually know about the relationship between arterial hypertension and atrial fibrillation? Blood Press 23: 81-88, 2014. https://doi.org/10.3109/08037051.2013.814234

TALMAN AH, PSALTIS PJ, CAMERON JD, MEREDITH IT, SENEVIRATNE SK, WONG DTL: Epicardial adipose tissue: far more than a fat depot. Cardiovasc Diagn Ther 4: 416-428; 2014

TEDROW UB, CONEN D, RIDKER PM, COOK NR, KOPLAN BA, MANSON JE, BURING JE, ALBERT: The long- and short-term impact of elevated body mass index on the risk of new atrial fibrillation the WHS (women's health study). J Am Coll Cardiol 55: 2319-2327, 2010. https://doi.org/10.1016/j.jacc.2010.02.029

THANASSOULIS G, MASSARO JM, O'DONNELL CJ, HOFFMANN U, LEVY D, ELLINOR PT, WANG TJ, SCHNABEL RB, VASAN RS, FOX CS, BENJAMIN EJ: Pericardial fat is associated with prevalent atrial fibrillation: the Framingham Heart Study. Circ Arrhythm Electrophysiol 3: 345-350, 2010. https://doi.org/10.1161/CIRCEP.109.912055

THRALL G, LANE D, CARROLL D, LIP GY: Quality of life in patients with atrial fibrillation: a systematic review. Am J Med 119: 448 e441-419, 2006. https://doi.org/10.1016/j.amjmed.2005.10.057

TKACOVA R, RANKIN F, FITZGERALD FS, FLORAS JS, BRADLEY TD: Effects of continuous positive airway pressure on obstructive sleep apnea and left ventricular afterload in patients with heart failure. Circulation 98: 2269-2275, 1998. https://doi.org/10.1161/01.CIR.98.21.2269 
TRAVERS JG, KAMAL FA, ROBBINS J, YUTZEY KE, BLAXALL BC: Cardiac fibrosis: the fibroblast awakens. Circ Res 118: 1021-1040, 2016. https://doi.org/10.1161/CIRCRESAHA.115.306565

VOSKOBOINIK A, KALMAN JM, DE SILVA A, NICHOLLS T, COSTELLO B, NANAYAKKARA S, PRABHU S, STUB D, AZZOPARDI S, VIZI D, WONG G, NALLIAH C, SUGUMAR H, WONG M, KOTSCHET E, KAYE D, TAYLOR AJ, KISTLER PM: Alcohol abstinence in drinkers with atrial fibrillation. N Engl J Med 382: 20-28, 2020. https://doi.org/10.1056/NEJMoa1817591

WANG TJ, LARSON MG, LEVY D, VASAN RS, LEIP EP, WOLF PA, D'AGOSTINO RB, MURABITO JM, KANNEL WB, BENJAMIN EJ: Temporal relations of atrial fibrillation and congestive heart failure and their joint influence on mortality: the Framingham Heart Study. Circulation 107: 2920-2925, 2003. https://doi.org/10.1161/01.CIR.0000072767.89944.6E

WANG TJ, PARISE H, LEVY D, D'AGOSTINO RB, SR., WOLF PA, VASAN RS, BENJAMIN EJ: Obesity and the risk of new-onset atrial fibrillation. JAMA 292: 2471-2477, 2004. https://doi.org/10.1001/jama.292.20.2471

WONG CX, SUN MT, ODUTAYO A, EMDIN CA, MAHAJAN R, LAU DH, PATHAK RK, WONG DT, SELVANAYAGAM JB, SANDERS P, CLARKE R: Associations of Epicardial, Abdominal, Overall Adiposity With Atrial Fibrillation. Circ Arrhythm Electrophysiol 9: 2016. https://doi.org/10.1161/CIRCEP.116.004378

YUN JP, CHOI EK, HAN KD, PARK SH, JUNG JH, PARK SH, AHN HJ, LIM JH, LEE SR, OH S: Risk of Atrial Fibrillation According to Cancer Type: A Nationwide Population-Based Study. JACC CardioOncol 3: 221-232, 2021. https://doi.org/10.1016/j.jaccao.2021.03.006

ZARICH SW, KOWALCHUK GJ, MCGUIRE MP, BENOTTI PN, MASCIOLI EA, NESTO RW: Left ventricular filling abnormalities in asymptomatic morbid obesity. Am J Cardiol 68: 377-381, 1991. https://doi.org/10.1016/0002-9149(91)90835-9

ZHAO L, LI S, MA X, BAI R, LIU N, LI N, SCHOENHAGEN P, MA C: Prognostic Significance of Left Ventricular Fibrosis Assessed by T1 Mapping in Patients with Atrial Fibrillation and Heart Failure. Sci Rep 9: 13374, 2019. https://doi.org/10.1038/s41598-019-49793-8

ZHOU Y, ZHOU J, SUN B, XU W, ZHONG M, LI Y, HE C, CHEN Y, WANG X, JONES PM, SUN Z: Vitamin A deficiency causes islet dysfunction by inducing islet stellate cell activation via cellular retinol binding protein 1. Int J Biol Sci 16: 947-956, 2020. https://doi.org/10.7150/ijbs.37861 